\title{
Media Outlets in Vojvodina and Slovenia: Demographic-economic Indicators and Media Pluralism
}

\author{
Dinko Gruhonjić ${ }^{A *}$, Smiljana MilinkovA, Miloš Katić ${ }^{B}$ \\ Received: February 04, 2021 | Revised: April 04, 2021 | Accepted: April 06, 2021 \\ doi: 10.5937/gp25-30710
}

\begin{abstract}
The paper analyzes the relationship between demographic-economic indicators in the Autonomous Province of Vojvodina and the Republic of Slovenia. Both societies have relatively organized regulatory and political frameworks for the development of media pluralism. It has been established that there is a clear cause-effect relation between the number of media outlets in certain local self-governments and the average net salary: the municipalities and towns with the highest average salaries also boast the highest number of media outlets. However, our analysis has shown that the criteria and mechanisms for identifying risks to media pluralism are not provided: the variety of population representing different political, ideological, cultural and social groups and the variety of interests and standpoints relevant to the local and regional community.
\end{abstract}

Keywords: media outlets; economics; demography; pluralism

\section{Introduction}

In terms of their territorial coverage, media outlets are classified as national, regional or local. In this paper, our focus is on local media outlets, i.e., on the classification and statistical data treatment related to the number of registered media outlets in relation to the local self-government in which they are registered, using the examples from the Autonomous Province of Vojvodina in the Republic of Serbia and the Republic of Slovenia.

According to the Statistical Office of the Republic of Serbia (2019), the population of the Autonomous Province of Vojvodina in 2019 was 1,852,093. According to Eurostat, the population of Slovenia on January 1, 2020 was 2,095,900 (Eurostat, 2020).

Even though these two territories have a different constitutional-legal status (a province within a stat vs. an independent state), Vojvodina and Slovenia were selected for this quantitative analysis due to similar population, similar size (the Republic of Slovenia ${ }^{1}$ $20,271 \mathrm{~km}^{2}$, the Autonomous Province of Vojvodina ${ }^{2}$ $-21,506 \mathrm{~km}^{2}$ ), and the common past that the two entities shared during two Yugoslav state unions (19181991). On the other hand, the social-political context within which the media system operates is different:

1 Data from the official site of the government of the Republic of Slovenia. https://www.gov.si/podrocja/drzava-in-druzba/oslovenijil. Visited on January 8, 2021.

2 Data from the site of the provincial government. http://www. vojvodina.gov.rs/sr/\%Do\%Bo\%D $1 \% 83 \% \mathrm{D}_{1} \% 82 \% \mathrm{Do} \% \mathrm{BE} \% \mathrm{D}$ o\%BD\%Do\%BE\%Do\%BC\%Do\%BD\%Do\%Bo-\%Do\%BF\%Do \%BE\%Do\%BA\%D1\%80\%Do\%Bo\%D1\%98\%Do\%B8\%Do\%BD \%Do\%Bo-\%Do\%B2\%Do\%BE\%D1\% 98\%Do\%B2\%Do\%BE\%Do\%B4\%Do\%B8\%Do\%BD\%Do\%Bo. Visited onJanuary 8, 2021.

A University of Novi Sad, Faculty of Philosophy, Department of Media studies, Vojvodina, Serbia;

dinko.gruhonjic@ff.uns.ac.rs; smilinkova@ff.uns.ac.rs;

в Executive director of the Independent Journalists' Association of Vojvodina, Novi Sad, Serbia; milos.katic@ndnv.org

* Corresponding author: Dinko Gruhonjić; e-mail: dinko.gruhonjic@ff.uns.ac.rs 
the Republic of Slovenia has been a member of the European Union since 2004, while the Republic of Serbia has had the status of a candidate country for EU membership since 2012 .

There are 45 municipalities and towns on the territory of Vojvodina, functioning as units of local self-government within seven districts, whose centers are the cities of Subotica, Zrenjanin, Kikinda, Pančevo, Sombor, Novi Sad and Sremska Mitrovica (Provincial Government). The municipalities and towns are run by the assemblies of local self-governments, town/municipal councils and the mayor/president of the municipality.

In the Republic of Slovenia, local self-governments function within municipalities and other local communities. The municipalities are run by three independent bodies: the mayor, the municipal council and the supervisory board. There are 212 municipalities in Slovenia, 11 of which have a status of city municipalities (Government of the Republic of Slovenia).

Pursuant to the Recommendations of the Council of Europe (2018), apart from independent and sustainable public broadcasting services, local media outlets can be a counterpoise to the increasingly dense concentration of media outlets. Furthermore, the media in local communities are particularly suitable for meeting the interests of local users. That is why states, as the final guarantors of media pluralism, need to provide suitable regulatory and political frameworks as a necessary precondition for the development of media pluralism. Consequently, states are obliged to provide the criteria and mechanisms for identifying the risks to medial pluralism: the diversity of ownership of media sources and media outlets themselves; the diversity of media outlet types; the diversity of population representing various political, ideological, cultural and social groups, as well as the diversity of interests and standpoints relevant to the local and regional community.

The aim of this paper is to use a comparative analysis of the number of registered media outlets and their territorial distribution to compare the specific features of the media market in the Republic of Slovenia and the Autonomous Province of Vojvodina.

The main investigative question is whether the average net salary per capita in the municipalities and cities has an impact on the number of local media outlets in local self-governments in Slovenia and Vojvodina. Furthermore, the paper analyses the factors that impact the functioning of media market and survival of media outlets on the local level. By analyzing the average number of media outlets in Vojvodina and Slovenia per one unit of self-government and the average net salary in the same local self-government, authors wanted to establish whether there is a cause-effect relation between the two criteria or whether we are talking about demographic-economic deviations and anomalies. Through such analysis, authors wanted to show how all that is reflected on the media pluralism in Vojvodina and Slovenia, i.e., to answer the investigative question whether the number of media outlets is in direct relation towith meeting the media pluralism criteria or not.

\section{Methodological framework}

A theoretical-empirical approach was used in the paper, through a descriptive method and comparative analysis of statistical data.

The necessary information regarding the number of local media outlets is provided by submitting a request to the Serbian Business Registers Agency, since it is the institution in charge of keeping records of legal entities operating on the territory of Serbia. The information regarding the average net salary was obtained through the portal of the Parliamentary Budget Office. The information regarding the average salary in the Republic of Slovenia and the number of media outlets in the municipalities and cities in this country was obtained through the portal of the Statistical Office of Slovenia.

The data were processed statistically using the statistical open-source software - Jamovi softwareversion 0.9.2.8 (2018). A t-test was used, with the level of statistical significance set to $\mathrm{p}<0.05$. A statistically significant difference was noticed in relation to the number of registered media outlets between the analyzed units of self-governments on the territory of Vojvodina $(\mathrm{p}<0.001)$. A statistically significant difference was noticed in relation to the number of registered media outlets in the analyzed municipalities on the territory of the Republic of Slovenia $(\mathrm{p}<0.00001)$.

\section{Role of local media outlets in society}

The media outlets that are territorially defined towards the community in which they were established, regardless of the type of ownership and financing are called local media outlets. As explained by Milojević and Krstić (2012), these media outlets are an expression tool of pluralism and diversity of a society and 
a mediator in the dialogue between local population and representatives of authorities. "They are a forum for voicing opinions and specific problems of local communities, which are not given enough space in the agenda of national and regional media outlets" (Milojević\& Krstić, 2012, str. 104).

Local media outlets are very important for media pluralism in a society. This claim is confirmed by numerous international documents, such as the recommendations of the Council of Europe, which encourage the development of local media outlets.

"Different types of media, along with different genres or forms of editorial content or programming, contribute to the diversity of content. Although content focusing on news and current affairs is of most direct relevance for fostering an informed society, other genres are also very important. Examples include cultural and educational content and entertainment, and content aimed at specific sections of society, such as local content and content aimed at vulnerable groups, such as minorities or persons with disabilities" (Recommendation of the Council of Ministers of the Council of Europe).

According to the same recommendation, states should encourage and support the establishment and functioning of minority, regional, local and not-for- profit community media by providing financial mechanisms to foster their development. Such independent media give a voice to communities and individuals on topics relevant to their needs and interests. Thus, such media are instrumental in creating public exposure for issues that may not be represented in the mainstream media.

Local media should contribute significantly to the development of local public sphere. Lang (2004) states that local political communication, whose important segment are local media, is the necessary precondition for citizens' engagement and democratic practice.

According to Mihajlov Prokopović (2018), unlike the socialist period in Yugoslavia, when local media were mostly state-owned in a sense that they were established and financed by local self-governments, during the last decade of the 20th century commercial media were being established rapidly and there were around 1,200 of them on the territory of Serbia in 2002, most of which (90 percent) were radio and TV stations. The 2002 Broadcasting Act envisaged a limited number of frequencies for electronic media. The procedure of granting licenses ended in 2008, by which time the broadcasting permit had been issued to 467 media outlets, 376 of which were local broadcasters (Mihajlov Prokopović, 2018).

\section{Demographic and economic indicators}

In 2019, according to the data of the Statistical Office of the Republic of Serbia, the province of Vojvodina had a population of $1,852,093$, living in 45 municipalities and cities, i.e. in 467 settlements. The total area of Vojvodina is 21,506 square kilometers and 86 citizens live on one square kilometer. The largest city in Vojvodina is Novi Sad, which, according to the same source, had a population of 360,925 in 2019. It is followed by Subotica (population 136,475), Pancevo $(119,509)$, Zrenjanin $(115,797)$, Sombor $(78,472)$ and Sremska Mitrovica $(75,241)$. The Statistical Office estimates that the population of Vojvodina decreased by 139,924 between 2012 and 2019, with Novi Sad the only of the listed cities to record a trend of growing population (its population increased by 17,277). All other major cities recorded a decrease in population.

According to Eurostat, on January 1, 2020, the population of Slovenia was 2,095,900, living in $212 \mathrm{mu}-$ nicipalities and cities. The total area of Slovenia is 20,271 square kilometers and 103 citizens live on one square kilometer. The population increased by 40,404 in comparison to 2012. According to the data of the Statistical Office of Slovenia, the most populated city was Ljubljana $(286,475)$, followed by Maribor $(96,211)$, Kranj (37,941), Celje $(37,872)$, Koper $(25,753)$, Velen- je $(25,594)$, Novo Mesto $(24,183)$ and Ptuj $(17,959)$. Among all the aforementioned cities, Ljubljana recorded the highest increase in population $(13,921)$ in comparison to 2012. Most other major municipalities and cities recorded slight increases in population (around one thousand).

The estimated population is calculated based on the data obtained from a census, information about the population growth and about internal migrations.

Based on the analyzed data regarding the number of registered media outlets in Vojvodina, it was established that only two municipalities in Vojvodina do not boast a registered media outlet and those municipalities are Ada and Čoka. According to the records of the Serbian Business Registered Agency, the total number of registered media outlets in 2019 was 761 . The highest number of media outlets were registered in Novi Sad (371), followed by Subotica (68) and Pančevo (42).

The average net salary on the territory of AP Vojvodina in 2019 was RSD 51,965 net (Parliamentary Budget Office, 2019), i.e., EUR 441,94(according to the middle exchange rate of NBS for 2019). The units of local self-government with average net salaries higher than the average salary in the province are Novi Sad (EUR 514,24), Vršac (EUR 480,13), Pančevo (EUR 


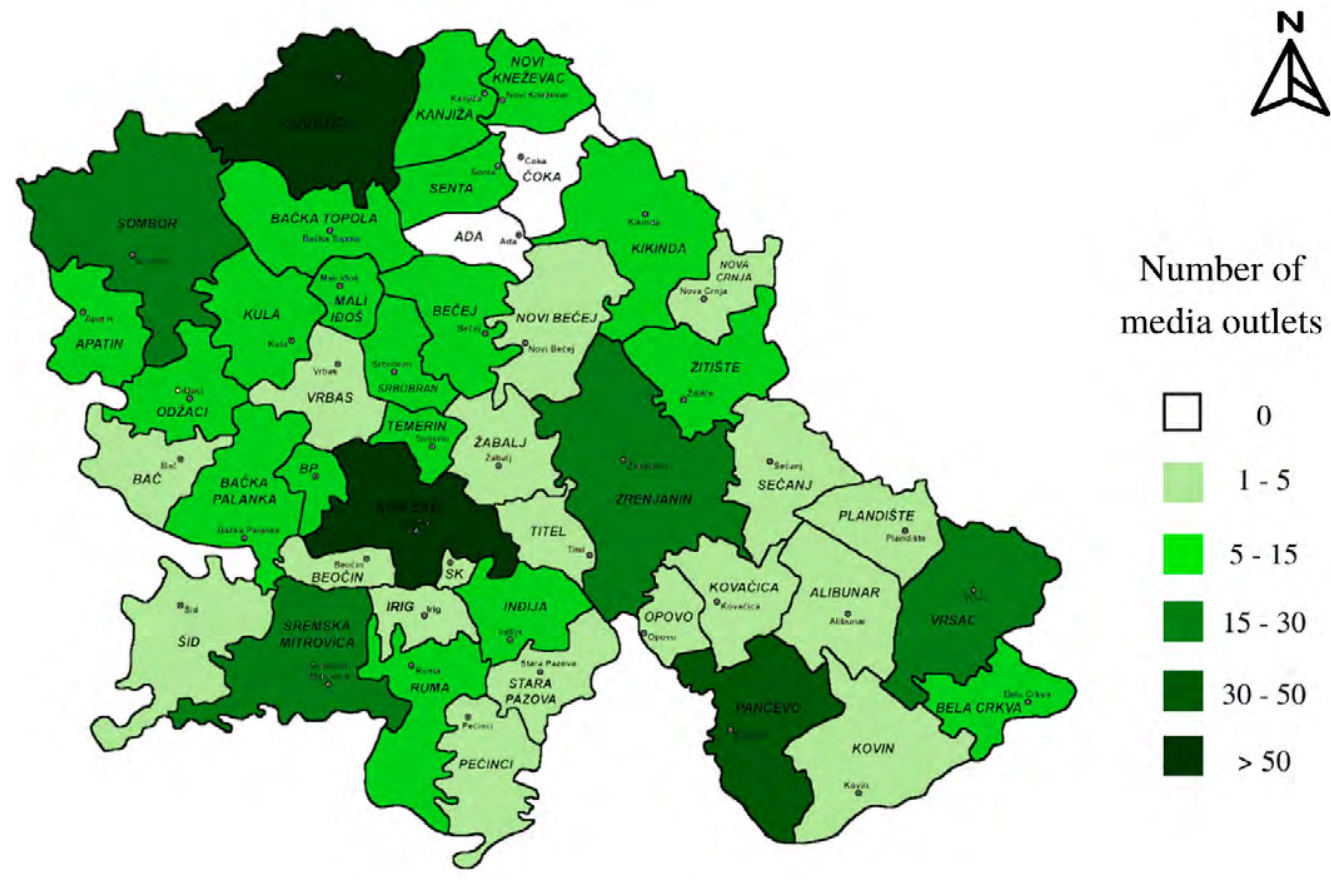

Figure 1. Number of media outlets in local self-governments in Vojvodina

460,38), Titel (EUR 450,11), Zrenjanin (EUR 448,35) and Kovin (EUR 443,33).

The units of local self-governments with net salaries above the provincial average boast 459 media outlets, i.e., 60.31 percent of the total number of registered media outlets are located in those six municipalities and cities.

According to the analyzed data related to the media outlets in Slovenia, the number of registered outlets in this country is 2,052. Most media outlets have been registered in Ljubljana - 1065, followed by Maribor (167) and the municipality of Koper (56 registered media outlets).

The average net salary in 2019 in Slovenia was EUR $1,133.50 .^{3}$ The municipalities with net salaries higher than the state average in Slovenia areNovo mesto (EUR 1,286), Ljubljana (EUR 1,282), Podlehnik (EUR 1,236), Mežica (EUR 1,196), Komenda (EUR 1,194),

3 https://pxweb.stat.si/SiStatData/pxweb/sl/Data/-/0772615S.px, visited on December 20, 2020.
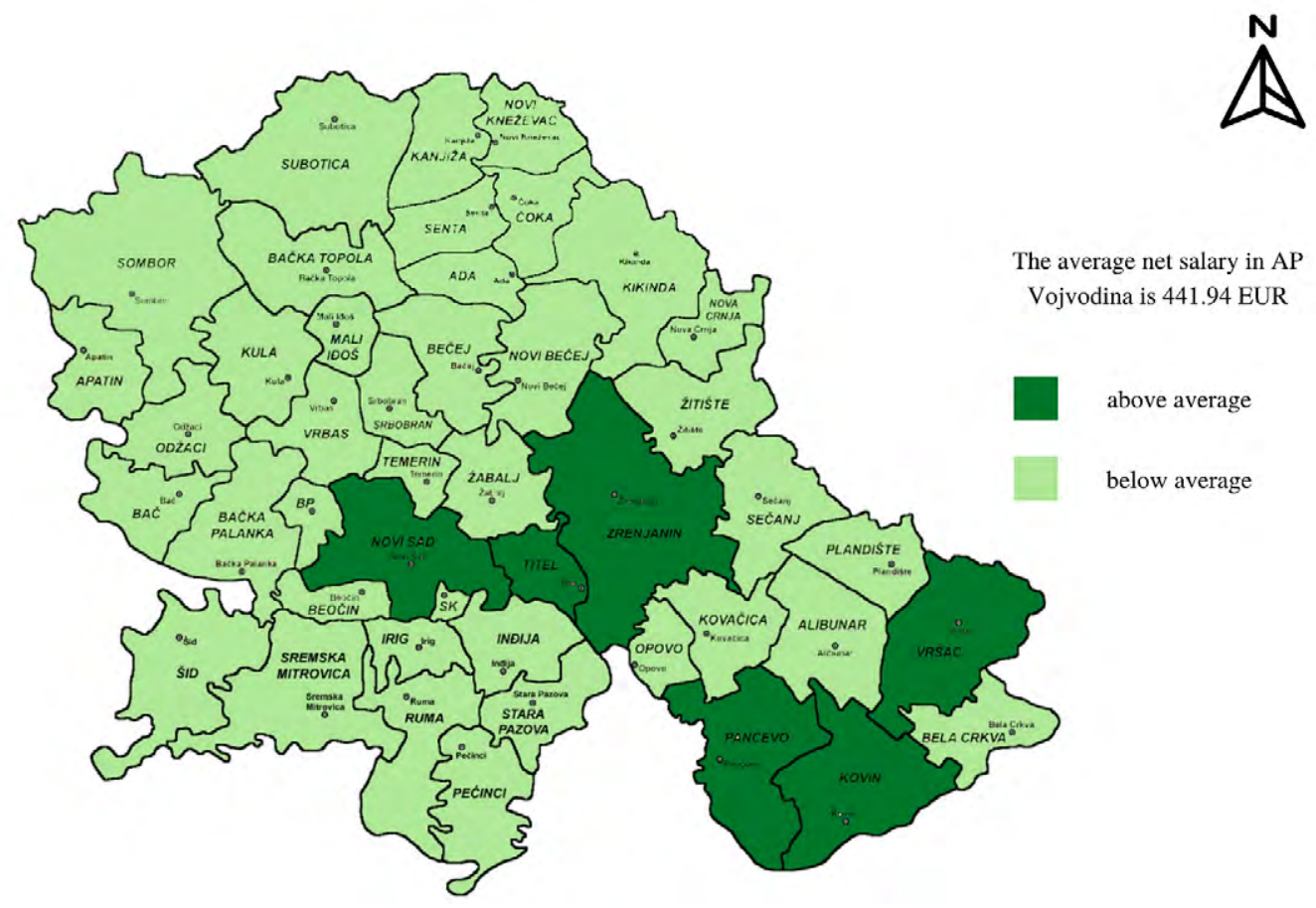

The average net salary in AP Vojvodina is 441.94 EUR

above average

below average

Figure 2. Average net salary in local self-governments in Vojvodina 


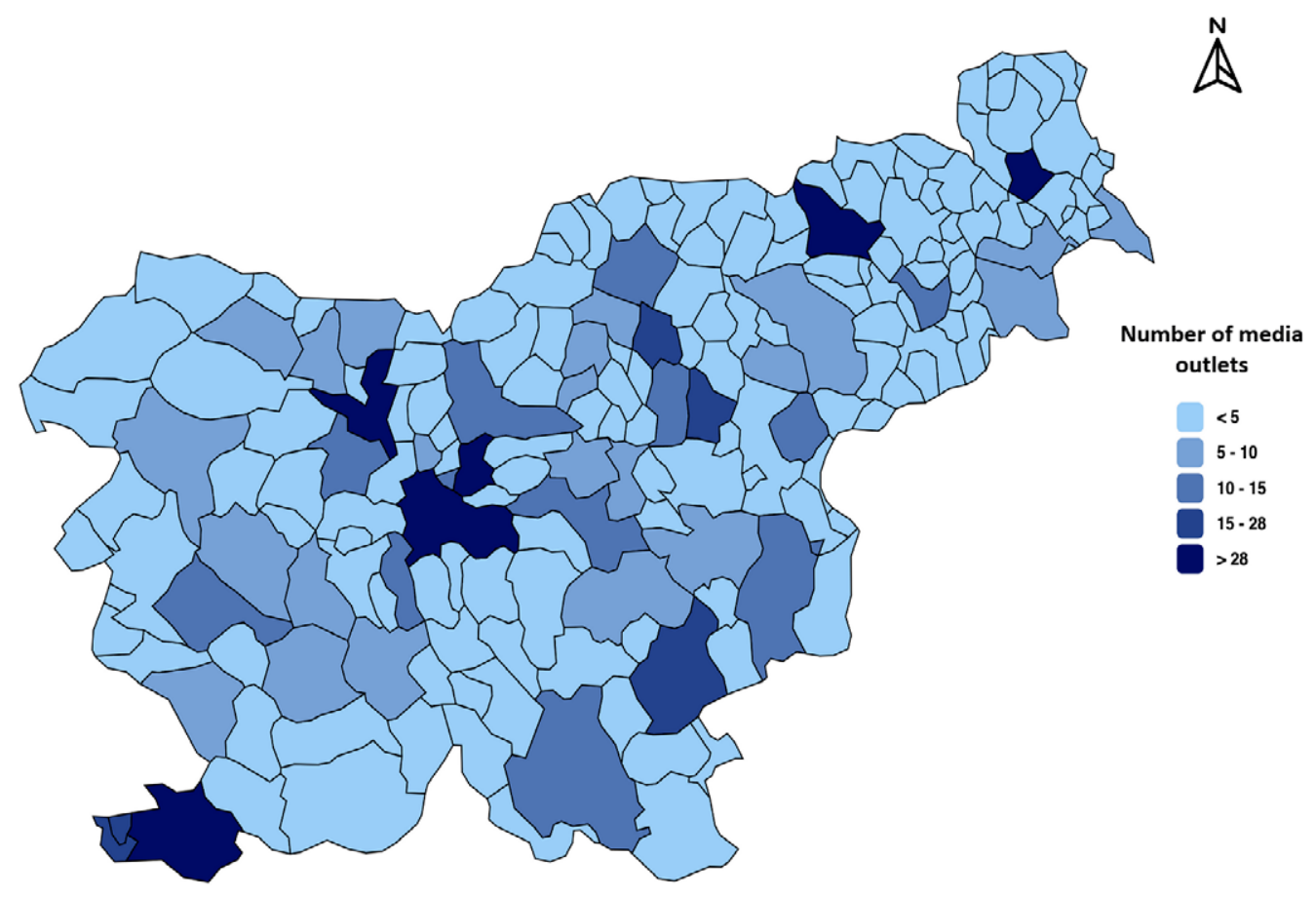

Figure 3. Number of media outlets in local self-governments in Slovenia

Dol pri Ljubljani (EUR 1,183), Štore (EUR 1,177), Koper (EUR 1,176), Zavrč (EUR 1,174), Krško (EUR 1,169), Lukovica (EUR 1,165), Škofja Loka (EUR 1,163), Idrija (EUR 1,162), Šentjernej (EUR 1,156), Šempeter - Vrtojba (EUR 1,151), Nova Gorica (EUR 1,140), Ravne na Koroškem (EUR 1,138), Križevci (EUR 1,134) and Šenčur (EUR 1,134).

The total number of registered media outlets in the municipalities with net salaries above the state average is 1,227 , i.e., 59,79 percent of the total number of registered media outlets are located in these municipalities.
In relation to the number of local self-governments, more media outlets are registered in Vojvodina than in Slovenia: 16.9 and 9.68 media outlets per one unit of self-government, respectively, despite the fact that the average net salary in Slovenia is 2.57 times higher than in Vojvodina and despite the fact that, as a consequence, the commercial potential of the media market in Slovenia is much bigger than in Serbia. Only two local self-governments in Vojvodina do not have a single media outlet registered in them. On the other hand, in Slovenia, 36 local self-
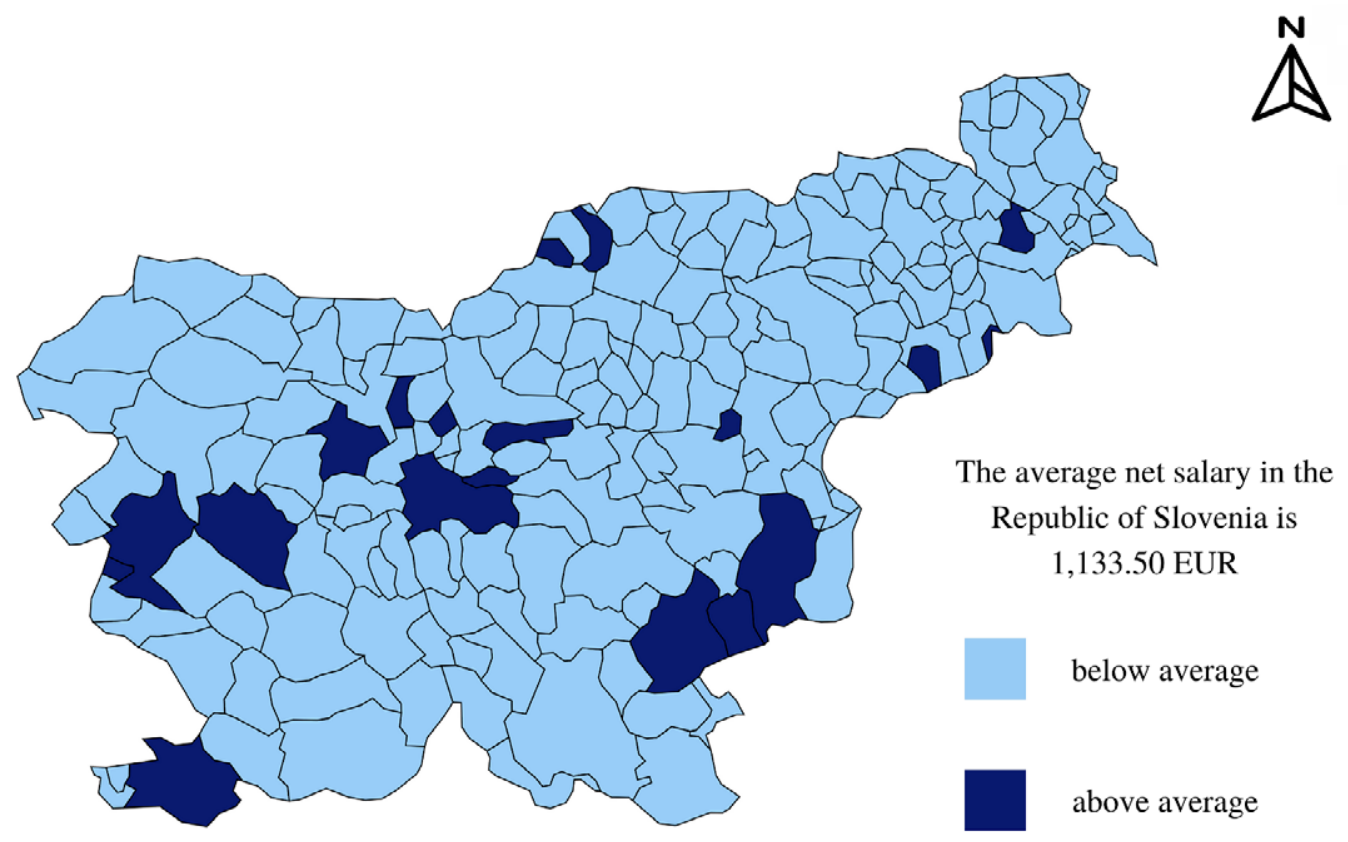

Figure 4. Average net salary in local self-governments in Slovenia 


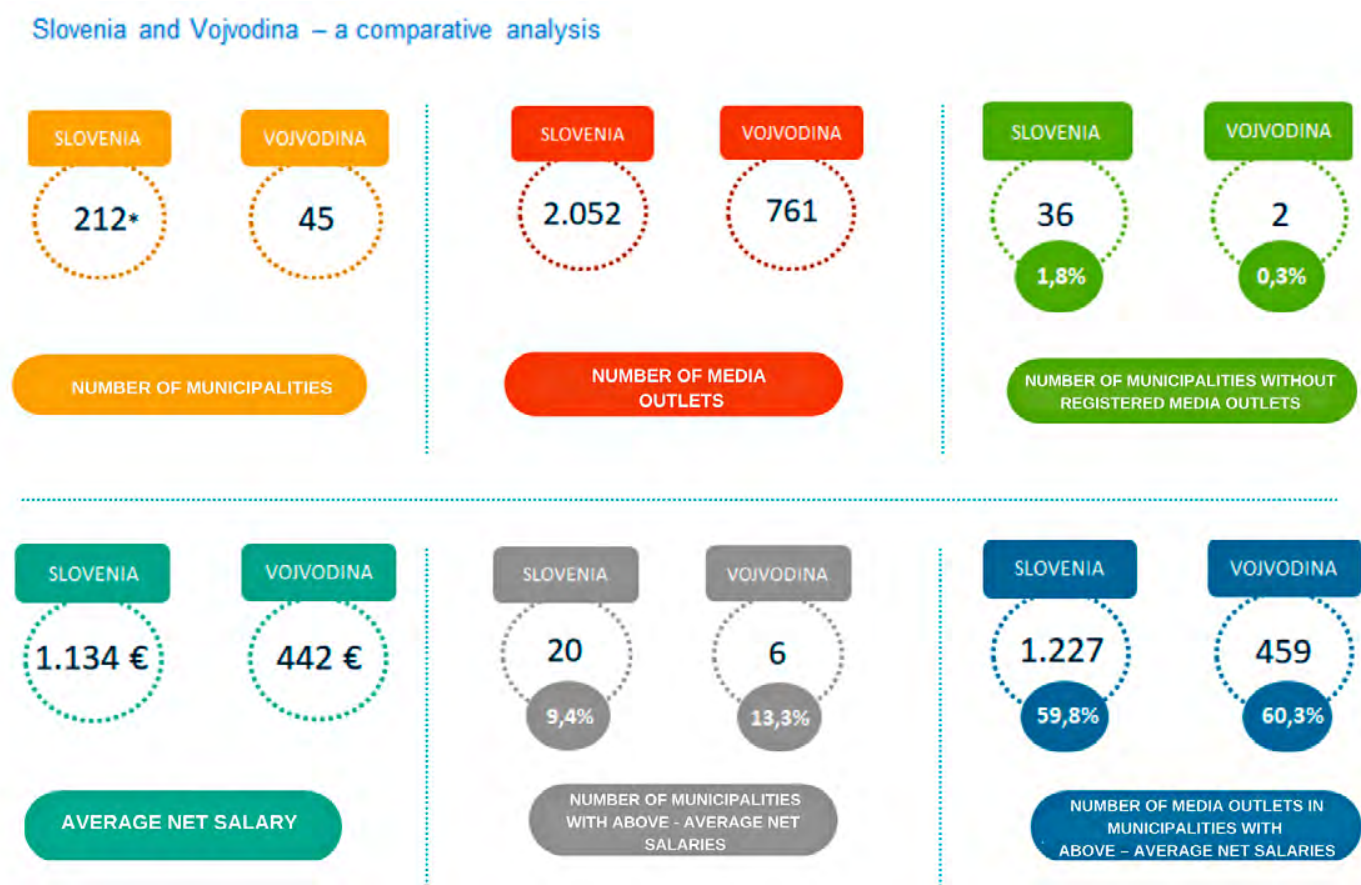

Figure 5. Comparative analysis of various quantitative indicators

governments do not have a single registered media outlet.

In Slovenia, there are 20 local self-governments with a higher average net salary than the state average, which is 9.4 percent of the total number of municipalities and cities, while there are six local self-governments in Vojvodina with a higher average net salary than the provincial average, which is 13.3 percent of the total number of municipalities and cities.

The number of media outlets in the municipalities with an above-average net salary in Vojvodina is 459, i.e., 60.3 percent, while there are 1,227 registered media outlets in the municipalities with an above-average net salary in Slovenia, which is 59.8 percent of the total number of registered media outlets in this country. In other words, the percentage is rather similar in Vojvodina and Slovenia, which is in line with the logic of media market, because a higher purchasing power provides a greater potential for advertising in media, which is the most important source of income for media outlets.

\section{The main problems on the media market in Slovenia}

In an analysis called "Monitoring of media pluralism in the digital era" (Milosavljevic \& Biljak Gerjevic, 2020), it is stated that, in a quantitative sense, the pluralism of media in Slovenia is satisfactory. The regulations for ensuring media pluralism are mostly clearly defined by laws and legal acts, but the implementation is often faulty. The reason for this is that many media outlets are publicly owned by political parties, their (former) members or open supporters of certain political options. This type of conflict of interest is particularly visible at local and regional levels. There are no efficient regularly protective mechanisms that would guarantee autonomy when it comes to appointing and releasing editors-in-chief. The state institutions in charge regularly publish annual calls for co-financing media content, but the amounts granted are very small, bearing in mind the number of media outlets.
The same analysis also states that there is a high risk when it comes to the concentration of media ownership, as well as the risk of controversial purchase and/ or merging of media outlets. Even though a consent of the Ministry of Culture is necessary when someone wishes to own more than 20 percent of a media outlet, breaches are still happening, since the ownership is easily concealed through off-shore companies. That is why expert analyses (Milosavljevic \& Biljak Gerjevic, 2020) emphasize the need for more resolute control of the authorities in charge, because four owners almost completely control the market of audio-visual products and print media in Slovenia.

This indicator of the concentration of online platform ownership also suggests a high level of risk related to media pluralism. In this field, there are no special rules about the control or prevention of media outlets merging and, consequently, concentra- 
tion of ownership. Some recent cases show that the concentration of ownership in media is growing stronger. This issue emerged when a telecommunication company "Telekom Slovenije" was allowed to establish a TV station Planet TV in 2012. There are many other companies engaged in multiple and simultaneous media activities and which continue to be issued licenses, despite legal restrictions. There were other, similar cases, such as the merger of the PoP TV broadcaster and Kanal A, which was an acquisition of Pro Plus, owned by the United Group, which owns the second largest telecommunication and cable operator Telemach. A similarly problematic situation was recorded when dailies Dnevnik and Večer were merged. "A high concentration of media ownership weakens pluralism and encourages selfcensorship among journalists", it was reported in the 2019 World Press Freedom Index (Reporters without borders, 2019).
Another high risk is related to the independence of media when it comes to the impact of commercial advertising on editorial policy. This field is also marked by a noticeable lack of regulations that would protect the independence of editorial policy. There are no regulations in place to ensure that the decisions regarding the appointment and release of editors-in-chief are not affected by commercial interests. Many cases of concealed advertising have also been recorded.

There is also a noticeable influence of Hungarian companies on the ownership of Slovenian media outlets. The Hungarian government is recognized in Europe as one of the greatest enemies of media freedom. This trend was also noticed by Freedom House, which stated that, having established almost a complete control over the media in Hungary, the ruling party in Hungary had started spreading the influence of the neoliberal policy of the Hungarian Prime Minister, Viktor Orban, in North Macedonia and Slovenia (Freedom House, 2019).

\section{Poverty and unregulated market of local media in Serbia}

The fact that a simple quantitative indicator related to the number of registered media outlets does not represent a solid base for concluding that there is media pluralism in a society is confirmed by numerous deviations on the media market in Serbia, where local media outlets are those in the most difficult financial situation, which often makes them exposed to various pressures and mechanisms of economic blackmailing.

The Law on Public Information and Media (2014) stipulates that a media outlet cannot be state-owned, except in the case of public broadcasting services. Therefore, according to the law, the media cannot be "directly or indirectly founded by the Republic, an autonomous province or a unit of local self-government, nor by an institution, company or other legal entity completely or partly owned by the state, i.e., which is completely or partly financed from public revenue".

In other words, the aforementioned law envisages the transformation of ownership over state-owned media, owned by the Republic of Serbia, an autonomous province, a unit of local self-government or public institutions and companies, which are financed from public revenue. The law obliges a buyer of a media outlet to ensure the continuity of placement of media content of public interest. "The privatisation of media referred to in paragraph 1 of this Article shall be organised in a manner which would enable the continuity in the production of media content of public interest over a period of five years from the conclusion of the agreement on the sale of capital, while other liabilities of the buyer stipulated in the contract may be de- fined for a period of up to five years since the concluding the agreement on sale of capital" (Law on Public Information and Media, Article 142).

Furthermore, the aforementioned law envisages cofinancing of projects that would secure public interest in the field of public information. "The Republic of Serbia, Autonomous Province and local self-government unit shall provide from their budgets part of the funding for realising public interest in the public information sector (hereinafter: public competition) and shall allocate the funds on the basis of public competitions and by way of allowances, in accordance with the principles of non-discrimination and the rules for state aid allocation and protection of competition." (Law on Public Information and Media, Article 17).Thereby, the Rulebook on co-financing projects related to ensuring public interest in the field of public information was adopted, which explains in details the mechanisms of project co-financing of public interest in the field of public information.

However, as stipulated in the Strategy of development of the public information system in the Republic of Serbia for 2020-2025 (the Media Strategy), a comprehensive analysis of the effects of project cofinancing content related to ensuring public interest has not been conducted. Reports on various elements of project co-financing reveal problems in the following fields: 1) method of announcing competitions and refusal of local self-governments to announce competitions, 2) method of selecting committee members and the composition of committees, 
3) non-transparency of competitions, 4) inclusion of discriminatory conditions, 5) inadequate monitoring system, 6) lack of evaluation of the quality of cofinanced content.

When it comes to the functioning of media market, the Media Strategy recognized the following most prominent problems: penurious media market, saturation due to a large number of outlets, advertising problems, contradictories and inconsistent enforcement of laws, non-transparent distribution of state funds based on vague criteria.

Previous research in Serbia (Matić, 2012; Milivojević et al., 2011) point at the monopolistic position of agencies dealing with selling advertising space and, thus, endangering the free market and, first and foremost, the position of local media outlets (according to Milojević $\&$ Krstić, 2012). These problems are also stipulated in the Media Strategy. The document stipulates that local and regional media outlets are losing the battle with those which have national coverage, and which are always included in opinion polls. To be more precise, as stipulated in the Media Strategy, as much as 89 percent of share in TV advertising belongs to TV stations with national coverage, while most of the remaining funds for advertising goes to foreign programs distributed through the cable network (Ipsos Strategic Marketing, 2015).The data show that out of 15 largest commercials advertisers in Serbia, not a single one advertises on local or even regional TV stations. Consequently, since local media outlets do not often attract interest of major advertising agencies, without which it is impossible to secure income from large advertisers, the pressure is further increased on the outlets to turn to various types of budget and state financing, including project co-financing, contracts with public companies, sponsorships and donations as the main source of income, thus introducing the state back on the stage as the dominant subject. According to a 2018 analysis of the Novi Sad School of Journalism, this situation diminishes the autonomy of local media outlets and creates a great space for various types of pressure, which are most commonly reflected in the impact on the media outlet's editorial policy and diminishment of its independent editorial policy. Hence, regional, local and civil society media outlets, have little or no income from advertising, which is why they are forced to generate income almost exclusively through co-financing competitions. In that manner, the competitions for media content financing are becoming almost the only source of income for local and regional media outlets. Project co-financing has, thus, turned into a social category, instead of competitions serving their primary function to provide funds for ensuring that public interest is met.

When it comes to the position of local media, the Media Strategy notes that the economic pressure imposed by local authorities, the lack of competitions, insufficient funds for project co-financing, disrespect towards laws and by-laws and favoring of certain media outlets when allocating funds have become the dominant forms of pressure on the independent editorial policy of local media outlets. This is also noted in the negative reports of the European Commission on the progress of Serbia towards EU, which state, among other problems, that "co-financing of media content to meet public interest obligations needs to be implemented in line with the legislative framework, using transparent and fair procedures, and without interference by the state administration, especially at local level,"(European Commission (2016), "Transparent ownership and funding of private media, state funding of media outlets and co-financing of media content need to be effectively monitored, including at local level, and implemented according to existing legislation," "Serbian authorities should ensure that informal pressure on editorial policy is not exerted through the distribution of advertising funds, including from public companies, as well as project cofunding from local budgets." (European Commission, 2018).

Apart from being extremely fragmented, the local media market is also economically unsustainable. Local media outlets have been in an extremely difficult situation for several years and they are operating on small, limited and extremely poor local/regional economic markets. They are making very little income from advertising and sales, while the transfer onto digital broadcasting of TV signals imposed new expenses on TV stations, which were not accompanied by increased revenue (Matić, 2016). Project co-financing, thus, becomes a model of financial sustainability of media outlets and serves as a tool for financing regular activities of the outlets, instead of being a tool to finance the missing content of public interests. Consequently, regular market relations cannot be developed, i.e., market relations are disturbed, especially on the local level.

4 „Non-Paper” on current state of affairs regarding chapters 23 and 24 for Serbia, November, 2017, pp. 8.Available at: https://bit. ly/2BVp8TO, visited onDecember 20, 2020. 


\section{Conclusion}

As already mentioned by quoting the recommendations of the Committee of Ministers of the Council of Europe", "Different types of media, along with different genres or forms of editorial content or programming, contribute to diversity of content." It is, therefore, not enough to have a lot of media outlets to claim there is media pluralism in a society, but there need to be various genres and program and editorial content for a society to be truly pluralistic when it comes to media. It is also not enough to have a legislative and political framework, which in theory is the main precondition for the development of media pluralism, but only under the condition that it is consistently enforced, which is a very common problem in Serbia in terms of the legislative framework. As a former commissioner for information of public importance and personal data protection, Rodoljub Šabić, noticed at a public event, the laws that are not enforced are not laws, but essays.

A statistical analysis of the number of media outlets in the Autonomous Province of Vojvodina and the Republic of Slovenia and of the economic indicators related to the average net salary in municipalities and cities, clearly shows that the average net salary per capita in the municipalities and cities has an impact on the number of local media outlets in local selfgovernments in Slovenia and Vojvodina. However, it is also clear that there are many more registered media outlets in Vojvodina than in Slovenia. This is undoubtedly an anomaly, because the average net salary, and consequently the potential for advertising in media, is more than two times higher in Slovenia than in Vojvodina. So, why are there so many media outlets in much poorer Vojvodina?

One of the reasons is definitely the fact that "the past two centuries have shown that without the support of mass media, traditional or internet, it is almost impossible to win the election or remain in power. Citizens (who are also voters) do not only experience the events in complex modern societies through their own experience, but they also create a picture of the world through media content: what, where, how and why did it happen?" (Kučić, 2019). If we add numerous problems related to the transparency of media financing on the local level, which are much more prominent in Vojvodina than in Slovenia, there is no other option, but to conclude that those are media outlets that do not take part in a fair competition. If we also consider the facts revealed in various research related to the deviations present in the process of project cofinancing of media content, where the media outlets close to the current authorities are favored, the lack of media pluralism becomes even more apparent. The editor of Kikindske, Željko Bodrožić, once estimated that project co-financing has turned into a "social category" and "bribing of their own media", while completely ignoring the law (beta.rs). The position of local media outlets in Vojvodina is made even more difficult by the fact that by far the largest part of income from advertising is taken by national media outlets, especially TV stations.

Along with an independent and sustainable public broadcasting service, the recommendations of the Council of Europe state that local media can also be a counterpoise to the increased concentration of media and that they could also be suitable for meeting the interest of local users. The results presented in this paper clearly show that it is not the case in Vojvodina, as part of Serbia. On the one hand, there is a relatively regulated legislative and political framework for the development of media pluralism. On the other hand, there are no criteria and mechanisms for identifying risks to media pluralism: diversity of media ownership and media outlets themselves; diversity of standpoints that represent political, ideological, cultural and social groups and the diversity of interests and standpoints relevant to local and regional communities.

\section{References}

Beta News Agency (2017). Authorities in Kragujevac have not organized competitions for co-financing media for three years. https://beta.rs/vesti/vesti-drustvo/65603-vlast-u-kragujevcu-tri-godinenije-raspisala-konkurs-za-sufinansiranje-medija (21.01.2021).

Broadcasting Act (2002).http://www.iaa.rs/assets/ZAKON-O-RADIODIFUZIJI.pdf (20.12.2020).

European Commission (2016). Republic of Serbia: 2016 Report, followed by the Commissions' com- munication addressed to the European Parliament, the Council, the European Economic and Social Committee and the Committee of the Regions regarding the EU enlargement policy for 2016, p. 22, available at: https://bit.ly/2EIycxT

European Commission (2018). Republic of Serbia: 2018 Report, followed by the Commissions' communication addressed to the European Parliament, the Council, the European Economic and Social Committee and the Committee of the Regions re- 
garding the EU enlargement policy for 2018, pp. 29. Available at: https://bit.ly/2rkgBlP (20.12.2020).

Eurostat (2020). EU population in 2020: almost 448 million, Available at: https://ec.europa.eu/eurostat/ documents/2995521/11081093/3-10072020-APEN.pdf/d2f799bf-4412-05cc-a357-7b49b93615f1 (20.12.2020).

Freedom House (2020). Media Freedom: A Downward Spiral. https://freedomhouse.org/report/freedom-and-media/2019/media-freedom-downwardspiral (21.01.2021).

Ipsos Strategic Marketing (2015). Analysis of media market in Serbia, pp. 15. Available at:http://www. rem.rs/sr/izvestaji-i-analize/izvestaji-i-analize-onadzoru-emitera/analize (20.12.2020).

Kučić, J, L (2019). Kdo drži informacijsko pištolo? Preiskujemo zemljevid medijske krajine. https://podcrto.si/kdo-drzi-informacijsko-pistolo-preiskujemo-zemljevid-medijske-krajine/ (21.01.2021)

Lang, S. (2004). Local Political Communication. In: F. Esser \& B. Pfetsch (Eds.) Comparing Political Communication: Theories, Cases and Challenges (pp.151-183). New York: Cambridge University Press. DOI:10.1017/CBO9780511606991.008

Matić, J. (2016). Structural causes of crisis and strategic solutions for economic sustainability of media. Talk at the Speak up! 3 conference: towards current media policy, Belgrade.

Mihajlov Prokopović, A. (2018). Siromašni lokalni mediji, siromašna demokratija. U A. Milojević \& R. Veljanovski. (ured.) Verodostojnost medijaodnos finansiranja i sadržaja (str. 133-135). [Poor local media, poor democracy. In A. Milojević \& R. Veljanovski (Eds.) Credibility of media - relation between financing and content (pp. 133153)]. Belgrade: Faculty of Political Science and Čigoja štampa.

Milojević, A., Ugrinić, A. (2012). Perspektiva lokalnih komercijalnih radio stanica u Srbiji. U: R. Veljanovski (ured.) Radio-difuzija u Srbiji, sadašnjost i budućnost (str. 103-127). [Future of local commercial radio stations in Serbia. In: R. Veljanovski (Ed.) Public radio-broadcasting in Serbia, present and future (pp.103-127)]. Belgrade: Faculty of Political Science and Čigoja štampa. URL: https://www. fpn.bg.ac.rs/wp-content/uploads/2017/01/Radiodifuzija-u-Srbiji-sadasnjost-i-buducnost.pdf

Milosavljevic, M, Biljak Gerjevic, R. (2020). Monitoring Media Pluralism in the Digital Era: Application of the Media Pluralism Monitor in the European Union, Albania and Turkey in the years 2018 2019. Country report: Slovenia. https://cadmus.eui. eu/bitstream/handle/1814/67818/slovenia results mpm 2020 cmpf.pdf?sequence=3. (21.01.2021).
Non-Paper" on the current state of affairs regarding chapters 23 and 24 for Serbia, November, 2017. Available at: https://bit.ly/2BVp8TO (20.12.2020)

Novi Sad School of Journalism (2018). Pressures on local media in Vojvodina. Novi Sad. Available at: http://www.novinarska-skola.org.rs/sr/?page $\mathrm{id}=2534$ \&lang=en, (20.12.2020).

Parliamentary Budget Office. http://pbk.rs/wp-content/uploads/2020/02/Prosecna zarada 2019.pdf. (14.12.2020).

Recommendation CM/Rec(2018)1[1] of the Committee of Ministers to members states on media pluralism and transparency of media ownership.https:// rm.coe.int/ser-cm-rec-2018-1-media-pluralismand-transparency-pdf/16809371eb

Reporters without borders (2019). Threats, systematic smear campaigns and media concentration. https:// rsf.org/en/slovenia (17.01.2020).

Republic of Serbia, Autonomous Province of Vojvodina, Provincial Government. http://www.vojvodina.gov.rs/sr/\%D0\%B0\%D1\%83\%D1\%82\%D 0\%BE\%D0\%BD\%D0\%BE\%D0\%BC\%D0\%BD\% D0\%B0-\%D0\%BF\%D0\%BE\%D0\%BA\%D1\%80 \%D0\%B0\%D1\%98\%D0\%B8\%D0\%BD\%D0\%B0\%D0\%B2\%D0\%BE\%D1\%98\%D0\%B2\%D0\%BE\%D0\%B4\%D0\%B8\%D0\%BD\%D0\%B0. (08.01.2021).

Republic of Slovenia, Ministry of Culture. https://rmsn.ekultura.gov.si/razvid/mediji?fbclid=IwAR3owaeK6lf6Y-ADWbylifyJsn72m25JfkPcFkDvY8zkNuT4R9L5Q7oC8Po (20.12.2020).

Republic of Slovenia, Statistical Office. Average net salaries in municipalities, Slovenia, annual report https://pxweb.stat.si/SiStatData/pxweb/sl/Data/L0772615S.px (20.12.2020).

Rulebook on co-financing projects for meeting public interest in the field of public information, https://www.paragraf.rs/propisi/pravilnik-sufinansiranju-projekata-oblasti-javnog-informisanja.html (20.12. 2020).

Statistical Office of the Republic of Serbia (2020). Municipalities and regions in the Republic of Serbia. https://publikacije.stat.gov.rs/G2020/Pdf/G202013047. pdf (27.03.2021).

Statistical Office of the Republic of Serbia (2019). Regions in the Republic of Serbia, 2019. https://publikacije.stat.gov.rs/G2020/Pdf/G202026001.pdf (20.12.2020).

Strategy of development of the public information system in the Republic of Serbia for 2020-2025. https://www.kultura.gov.rs/tekst/sr/4993/strategijarazvoja-sistema-javnog-informisanja-u-republicisrbiji-za-period-od-2020-do-2025.php (02.09.2020).

The Law on Public Information and Media https://www.paragraf.rs/propisi/zakon o javnom informisanju i medijima.html (10.01.2021) 